Gut, 1974, 15, 777-782

\title{
Enzyme histochemical study of fat absorption in human duodenal mucosa
}

\author{
H. MONGES, A. Chamlian, A. COUGARD, AND B. MATHiEU \\ From the Departments of Gastroenterology and Pathology, Hôpital Nord, Marseille-Cedex 3, France
}

SUMMARY In seven healthy subjects the activities of various intestinal enzymes were studied using a fasting control peroral biopsy and two other biopsies 15 minutes and 30 minutes after an intestinal infusion of emulsified corn oil.

Specific histochemical methods permitted the comparison of the enzymatic activities of the absorptive cells at the top of the villi before and during fat absorption which was demonstrated with a Sudan black stain.

Four oxydative enzymes were modified after the corn oil infusion: NADH2-tetrazolium reductase, NADPH2-tetrazolium reductase, glucose-6-phosphate dehydrogenase, and lactate dehydrogenase.

In six cases, the activity of NADH2-tetrazolium reductase was increased. Two of these subjects presented a simultaneous increase of NADPH2-tetrazolium reductase and glucose-6-phosphate dehydrogenase. Two other subjects presented a decrease in lactate dehydrogenase activity.

The development of peroral biopsy of the small intestine has permitted many investigations on the mode of fat absorption by the epithelial cells of the intestinal mucosa (Parmentier, 1962; Dobbins, 1968, 1969; Debray, Cerf, Marche, and Bertin, 1969). Furthermore, various enzymes involved in the absorption of fat were studied using biochemical methods, mainly in laboratory animals (Tuba and Robinson, 1953; Kern and Borgström, 1965; Lewis and Hunter, 1966; Kayden, Senior, and Mattson, 1967; Johnston, 1968). As yet, only a few papers have been devoted to enzyme histochemistry as a method allowing a direct study of the intraepithelial intestinal enzymes involved in fat absorption(Przelecka, Ejsmont, Sarzala, and Taracha, 1962; Barka, 1963; Wegmann, Housset, Guesde, and Nepveux, 1967; Higgins and Barrnett, 1971).

The purpose of this work is to compare the enzymatic activities in the absorptive cells of the human duodenal mucosa before and after an infusion of emulsified corn oil into the duodenal lumen.

\section{Material and Methods}

\section{SUBJECTS}

Tested subjects

Seven male volunteers, average age 45 years (range

Received for publication 20 June 1974.
30-62), with normal intestinal function were studied. They were biopsied after an overnight fast, without attempting prior dietary control. Immediately after a biopsy capsule had been introduced into the duodenum a specimen of duodenal mucosa was cut in order to determine the initial enzymatic activity of the absorptive cells. After instilling corn oil into the duodenum additional biopsies were taken at 15 minutes and at 30 minutes.

\section{Control subjects}

Four healthy subjects, average age 48 years (range 43-51), with a nutritional status identical to the tested subjects, were also studied. These subjects did not receive any fat and were submitted to three biopsies at 15-minute intervals in order to detect if any enzymatic modification of the duodenal mucosa was eventually induced by the biopsy tube.

\section{EXPERIMENTAL METHOD}

\section{Composition of the test meal}

Tested subjects received a purified corn oil (Germasol) in which the long chain fatty acids were distributed as9 $\%$ palmiticacid(16:0), 3\% stearicacid (18:0), $46 \%$ oleic acid (18:1), $41 \%$ linoleic acid (18:2) and $1 \%$ arachidic acid (20:2).

The test meal consisted of $30 \mathrm{ml}$ of corn oil and $60 \mathrm{ml}$ of water blended for five minutes before instillation. 
The biopsy tube

All the specimens of mucosa were obtained with a Debray suction biopsy capsule. The tissue sections were flushed through the hydraulic biopsy tube with a tyrode solution. A patent polyethylene tube was taped $1 \mathrm{~cm}$ above the capsular device to provide a means of instilling the corn oil emulsion into the duodenal lumen. The subjects had no topical pharyngeal anaesthetic and swallowed the biopsy tube without prior lubrication. After verifying fluoroscopically that the capsule was in the proximal portion of the second part of the duodenum, the emulsified corn oil was instilled over a period of two minutes. Then suction biopsies were obtained near the duodenojejunal junction.

\section{Manipulation of intestinal biopsies}

Immediately after they were obtained, the mucosal samples were collected on a tissue mesh, carefully placed, cut side down, on a piece of cardboard and immersed for four seconds in liquid nitrogen. The samples collected before and after the instillation of oil were mounted together in order to allow a direct comparison of respective enzymatic activities. Sections $12 \mu$ thick were then cut in a cryostat at $-18^{\circ} \mathrm{C}$, dried for five minutes at room temperature, and processed for histochemical reactions.

\section{HISTOCHEMISTRY}

Lipid stain

Unfixed sections were placed for 30 minutes in a saturated solution of Sudan black.

\section{Enzyme histochemical reactions}

The following histochemical enzyme determinations were carried out: succino-dehydrogenase (Wegmann and Tordet-Caridroit, 1960), lactate dehydrogenase (Nachlas, Walker, and Seligman, 1958), glucose-6phosphate dehydrogenase (Wegmann and Gerzeli, 1961), reduced nicotinamide adenine dinucleotide tetrazolium reductase (Scarpelli, Hess, and Pearse, 1958), reduced nicotinamide adenine dinucleotide phosphate tetrazolium reductase (Scarpelli et al, 1958), alkaline phosphatase (Gomori, 1941), acid phosphatase (Gomori, 1942) adenosine triphosphatase (Padykula and Herman, 1955), non-specific esterase (Nachlas and Seligman, 1949), and $\beta$ glucuronidase (Seligman, Tsou, Rutenburg, and Cohen, 1954).

For dehydrogenase reactions, the sections were incubated at $37^{\circ} \mathrm{C}$ and the NBT salt reaction was used as an electron acceptor. For each histochemical procedure, a control section was incubated in a medium without a substrate.

At the top of the villi where the greatest lipid absorption occurred, the modifications of the enzymatic activities of the absorptive cells were noted by two observers on the following scale: 0 negative reaction, + weak reaction, ++ moderate reaction, +++ strong reaction, and ++++ very strong reaction.

\section{Results}

\section{THE TESTED SUBJECTS}

None of the seven cases showed lipid droplets in the absorptive cells of the duodenal mucosa collected before the fat infusion (fig 1A) whereas, after the corn oil instillation, the appearance of numerous sudanophilic droplets in the epithelial absorptive cells provided significant evidence for fat absorption (fig 1C).

In six cases, the absorptive process was evident 15 minutes after the fat infusion; however, in one case it was only evident 30 minutes after the infusion.

When lipid absorption was important, the sudanophilic globules accumulated in the apical part of the cytoplasm appearing as a large, densely stained, supranuclear band. Rows of small droplets also occurred in the intercellular spaces (fig 1C).

Of the 10 enzymatic reactions, four presented obvious modifications during the corn oil absorption and six never varied. The enzymes with modified activities were: reduced nicotinamide adenine dinucleotide tetrazolium reductase (NADH2-TR), reduced nicotinamide adenine dinucleotide phosphate tetrazolium reductase (NADPH2-TR), glucose6-phosphate dehydrogenase (G-6-PD), and lactate dehydrogenase (LD).

Both the NADH2-TR and the NADPH2-TR presented strong enzymatic activity in the samples of mucosa collected before infusion.

The reaction products appeared as numerous mono- and di-formazan granules strongly staining the apical part of the columnar absorptive cells and faintly visualized in the lateral and basal regions of these cells.

Of the seven test cases, one showed no enzymatic variations during fat absorption. In six cases, NADH2-TR activity increased during the fat absorption, and in three of these six subjects a concomitant activation of NADPH2-TR was observed. In two of these three cases glucose-6phosphate dehydrogenase (G-6-PD) was also augmented. The increase in these enzymatic activities only occurred when fat absorption was important (fig 1C-D).

One subject presented enzymatic activation 30 minutes after the infusion, but in all other cases the increased activity was observed in the 15-minute samples and the 30-minute samples showed either a 

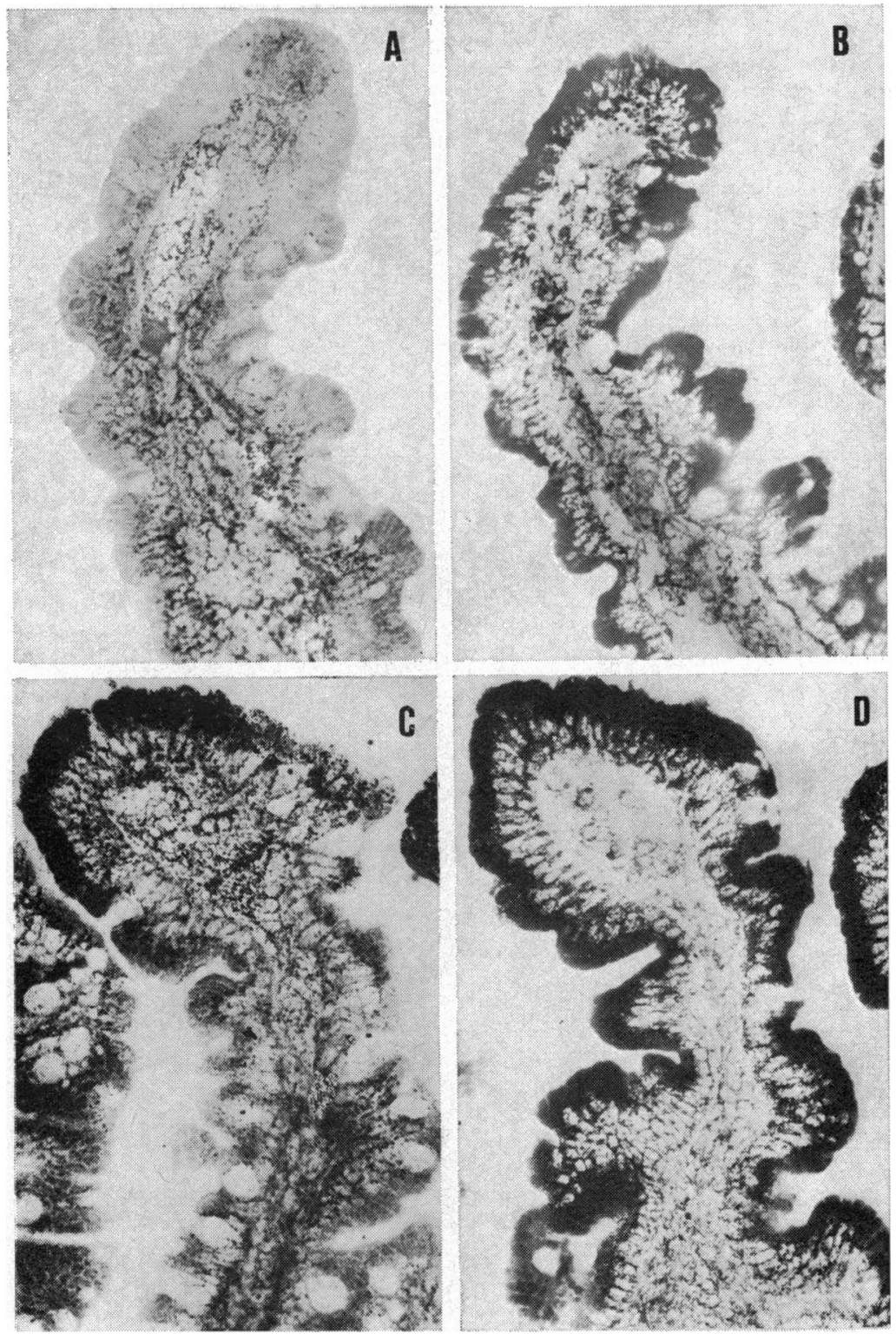

Fig 1 Activity of NADH2-tetrazolium reductase before and 15 minutes after corn oil infusion into the duodenal lumen. The lipids are visualized by a Sudan black stain.

Before corn oil instillation

A Sudan black stain. The absorptive cells do not contain sudanophilic droplets. In contrast, they are present in the lamina propria ( $\times 250)$.

B Enzyme histochemistry. A strong NADH2-tetrazolium reductase activity exists in the absorptive cells $(\times 250)$.

Fifteen minutes after corn oil instillation

C Sudan black stain. The fat absorption is evident in the duodenal epithelium. The apical pole of the absorptive cells contains numerous sudanophilic droplets and chylomicrons appear in the intercellular spaces $(\times 250)$.

D Enzyme histochemistry. The NADH2-tetrazolium reductase activity, compared with that observed before corn oil infusion, is greatly increased mainly at the apical pole of the absorptive cells $(\times 250)$. 

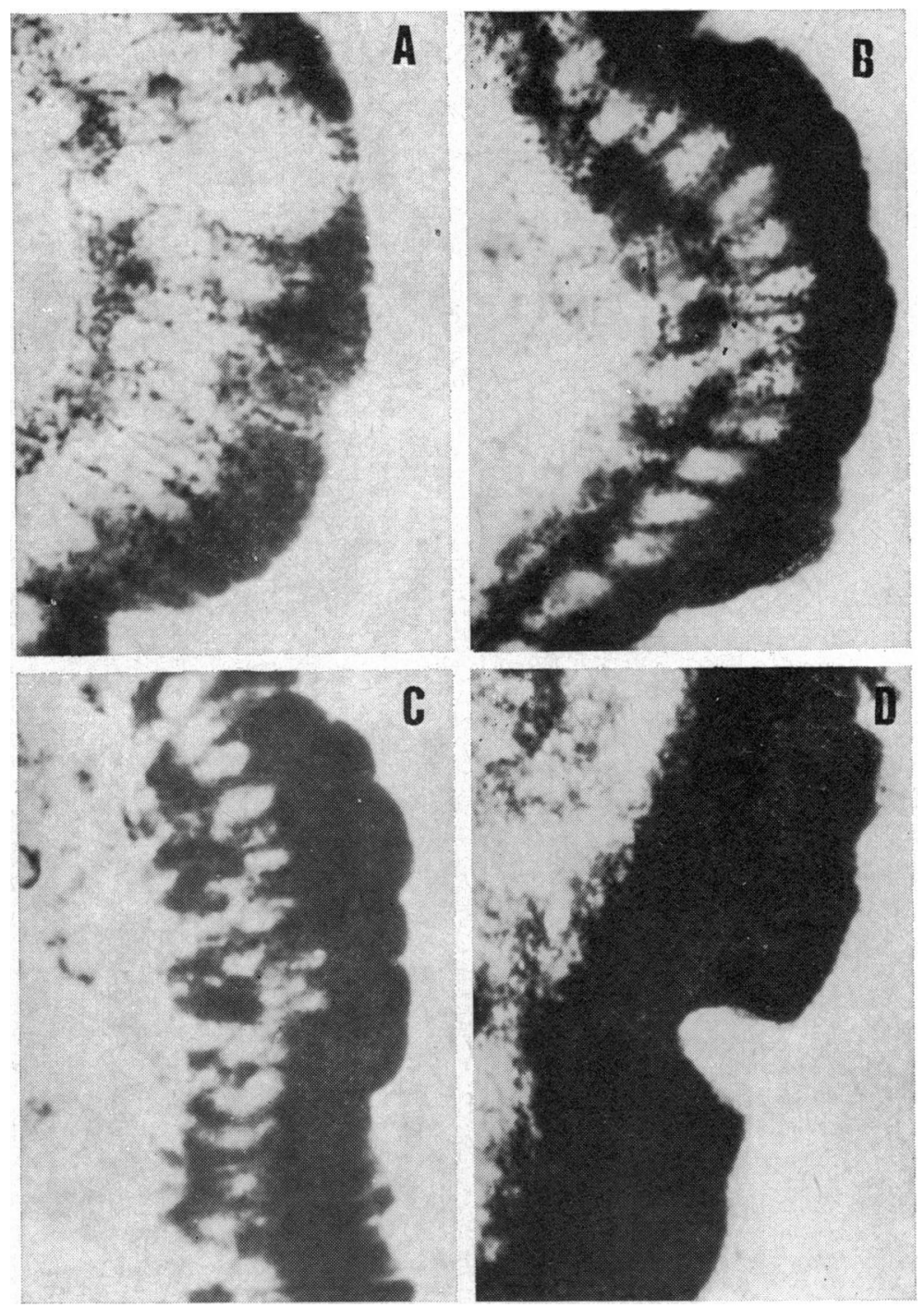

Fig 2 Activities of NADH2-tetrazolium reductase and NADPH2-tetrazolium reductase in the absorptive cells at the top of a duodenal villus before and 15 minutes after corn oil infusion into the duodenal lumen. Each of these enzymatic activities was appreciated in subjects that showed an evident fat absorption.

NADH2-tetrazolium reductase

A Before corn oil introduction, the enzymatic activity is strong at the apical pole of the cells and weak at the basal pole and perinuclear cytoplasm $(\times 400)$.

B Fifteen minutes after corn oil infusion, the activity increases at the apical pole, at the basal pole, and in the perinuclear cytoplasm of the absorptive cells $(\times 400)$.

NADPH2-tetrazolium reductase.

C Before corn oil infusion, enzymatic activity is strong in the cytoplasm of absorptive cells. The nuclei appear as negative images $(\times 400)$.

D Fifteen minutes after corn oil infusion, the enzymatic activity is stronger, and the formazan reaction obscures the nuclei $(\times 400)$. 


\begin{tabular}{|c|c|c|c|c|c|c|}
\hline \multirow[t]{2}{*}{ Case No. } & \multirow[t]{2}{*}{ Biopsy Samples } & \multirow{2}{*}{$\begin{array}{l}\text { Fat Staining } \\
\text { by Sudan Black }\end{array}$} & \multicolumn{4}{|c|}{ Enzymatic Activity } \\
\hline & & & $N A D H 2-T R$ & NADPH2-TR & $G-6-P D$ & $L D$ \\
\hline 2 & $\begin{array}{l}\text { Before corn oil infusion } \\
\text { Fifteen minutes after infusion } \\
\text { Thirty minutes after infusion } \\
\text { Before corn oil infusion } \\
\text { Fifteen minutes after infusion } \\
\text { Thirty minutes after infusion }\end{array}$ & $\begin{array}{l}0 \\
+++ \\
+++ \\
0 \\
+++ \\
++\end{array}$ & $\begin{array}{l}+++ \\
++++ \\
++++ \\
+++ \\
++++ \\
++++\end{array}$ & $\begin{array}{l}+++ \\
+++ \\
+++ \\
+++ \\
++++ \\
++++\end{array}$ & $\begin{array}{l}++ \\
++ \\
++ \\
++ \\
+++ \\
+++\end{array}$ & $\begin{array}{l}+++ \\
++ \\
++ \\
+++ \\
+++ \\
+++\end{array}$ \\
\hline 3 & $\begin{array}{l}\text { Before corn oil infusion } \\
\text { Fifteen minutes after infusion } \\
\text { Thirty minutes after infusion }\end{array}$ & $\begin{array}{l}0 \\
++ \\
++\end{array}$ & $\begin{array}{l}+++ \\
++++ \\
+++\end{array}$ & $\begin{array}{l}+++ \\
+++ \\
+++\end{array}$ & $\begin{array}{l}++ \\
++ \\
++\end{array}$ & $\begin{array}{l}+++ \\
+++ \\
++t\end{array}$ \\
\hline 4 & $\begin{array}{l}\text { Before corn oil infusion } \\
\text { Fifteen minutes after infusion } \\
\text { Thirty minutes after infusion }\end{array}$ & $\begin{array}{l}0 \\
+++ \\
++\end{array}$ & $\begin{array}{l}+++ \\
+++ \\
+++\end{array}$ & $\begin{array}{l}+++ \\
+++ \\
++t\end{array}$ & $\begin{array}{l}++ \text { to } t++ \\
++ \\
+\end{array}$ & $\begin{array}{l}++ \text { to } t+t \\
++ \\
++\end{array}$ \\
\hline 5 & $\begin{array}{l}\text { Before corn oil infusion } \\
\text { Fifteen minutes after infusion } \\
\text { Thirty minutes after infusion }\end{array}$ & $\begin{array}{l}0 \\
+++ \\
++\end{array}$ & $\begin{array}{l}+t+ \\
++++ \\
+++\end{array}$ & $\begin{array}{l}+++ \\
+++t \\
++t\end{array}$ & $\begin{array}{l}++ \\
+++ \\
+++\end{array}$ & $\begin{array}{l}++ \text { to } t+t \\
++ \text { to } t+t \\
+++\end{array}$ \\
\hline 6 & $\begin{array}{l}\text { Before corn oil infusion } \\
\text { Fifteen minutes after infusion } \\
\text { Thirty minutes after infusion }\end{array}$ & $\begin{array}{l}0 \\
+ \\
++ \text { to } t+t\end{array}$ & $\begin{array}{l}+++ \\
+++ \\
++++\end{array}$ & $\begin{array}{l}+t+ \\
++t \\
++t+\end{array}$ & $\begin{array}{l}+++ \\
+++ \\
+++\end{array}$ & $\begin{array}{l}++t \\
++t \\
++\end{array}$ \\
\hline 7 & $\begin{array}{l}\text { Before corn oil infusion } \\
\text { Fifteen minutes after infusion } \\
\text { Thirty minutes after infusion }\end{array}$ & $\begin{array}{l}0 \\
+++ \\
++\end{array}$ & $\begin{array}{l}+++ \\
+++t \\
++++\end{array}$ & $\begin{array}{l}++++ \\
++++ \\
+++t\end{array}$ & $\begin{array}{l}+++ \\
+++ \\
++t\end{array}$ & $\begin{array}{l}++ \\
++ \\
++\end{array}$ \\
\hline
\end{tabular}

Table I Response at the top of the villi of duodenal absorptive cells to corn oil infusion related to enzyme ${ }^{1}$ histochemical findings ${ }^{1}$

Negative reaction $(0)$, weak reaction $(+)$, moderate reaction $(++)$, strong reaction $(+++)$, very strong reaction $(++++)$.

\begin{tabular}{|c|c|c|c|c|c|c|}
\hline \multirow[t]{2}{*}{ Case No. } & \multirow[t]{2}{*}{ Biopsy Samples } & \multirow{2}{*}{$\begin{array}{l}\text { Fat Staining } \\
\text { by Sudan } \\
\text { Black }\end{array}$} & \multicolumn{4}{|l|}{ Enzymatic Activity } \\
\hline & & & $N A D H 2-T R$ & NADPH2-TR & $G-6-P D$ & $L D$ \\
\hline 1 & $\begin{array}{l}\text { Initial sample } \\
\text { Fifteen-minute sample } \\
\text { Thirty-minute sample }\end{array}$ & $\begin{array}{l}\mathbf{0} \\
\mathbf{0} \\
\mathbf{0}\end{array}$ & $\begin{array}{l}++t \\
+++ \\
++t\end{array}$ & $\begin{array}{l}++++ \\
++++ \\
++++\end{array}$ & $\begin{array}{l}+t \\
++ \\
++\end{array}$ & $\begin{array}{l}t+\text { to } t+t \\
++ \text { to } t+t \\
++ \text { to } t+t\end{array}$ \\
\hline 2 & $\begin{array}{l}\text { Initial sample } \\
\text { Fifteen-minute sample } \\
\text { Thirty-minute sample }\end{array}$ & $\begin{array}{l}\mathbf{0} \\
\mathbf{0} \\
\mathbf{0}\end{array}$ & $\begin{array}{l}+++ \\
+++ \\
+++\end{array}$ & $\begin{array}{l}++t \\
++t \\
++t\end{array}$ & $\begin{array}{l}++ \text { to } t+t \\
++ \text { to } t+t \\
++ \text { to }+++\end{array}$ & $\begin{array}{l}t+\text { to } t+t \\
++ \text { to } t+t \\
++ \text { to } t+t\end{array}$ \\
\hline 3 & $\begin{array}{l}\text { Initial sample } \\
\text { Fifteen-minute sample } \\
\text { Thirty-minute sample }\end{array}$ & $\begin{array}{l}\mathbf{0} \\
\mathbf{0} \\
\mathbf{0}\end{array}$ & $\begin{array}{l}+++ \\
+++ \\
+++\end{array}$ & $\begin{array}{l}+++ \\
+++ \\
+++\end{array}$ & $\begin{array}{l}++ \text { to }+++ \\
++ \text { to }+++ \\
+ \text { to }++\end{array}$ & $\begin{array}{l}++ \text { to }+++ \\
++ \text { to }+++ \\
++ \text { to }+++\end{array}$ \\
\hline 4 & $\begin{array}{l}\text { Initial sample } \\
\text { Fifteen-minute sample } \\
\text { Thirty-minute sample }\end{array}$ & $\begin{array}{l}\mathbf{0} \\
\mathbf{0} \\
\mathbf{0}\end{array}$ & $\begin{array}{l}+t+ \\
++t \\
+++ \text { to } t+t+\end{array}$ & $\begin{array}{l}+++ \\
+++ \\
++t\end{array}$ & $\begin{array}{l}+++ \\
+++ \\
+t+\end{array}$ & $\begin{array}{l}+t+ \\
t+t \\
t+t\end{array}$ \\
\hline
\end{tabular}

Table II Enzyme histochemical response of duodenal absorptive cells at the top of the villi without infusion of corn oil or water ${ }^{1}$

${ }^{1}$ Negative reaction $(0)$, weak reaction $(+)$, moderate reaction $(++)$, strong reaction $(+++)$, very strong reaction $(++++)$.

persisting enzymatic activation or a return to the initial level. In the absorptive cells, the increase of both NADH2-TR and NADPH2-TR was shown by an intracytoplasmic accumulation of mono- and diformazan granules (fig 2A-B). When the enzymatic activity was very strong the reaction products obscured nuclei which had appeared as negative images before enzyme activation (fig 2C-D).

In the preinstillation biopsies, the glucose-6phosphate dehydrogenase (G-6-PD) activity varied, according to subject, from weak to strong. During fat absorption the enzymatic level was unchanged in five cases, but in two it increased simultaneously with the NADH2-TR and NADPH2-TR.

The activity of the lactate dehydrogenase (LD) was reduced during fat absorption in two cases and was unchanged in five cases.

These enzyme histochemical findings are reported in table I.

\section{The control subjects}

In the control group, there were no enzymatic variations in the successive biopsies. The enzyme histochemical findings in this group are reported in table II.

\section{Discussion}

These histochemical data indicate that after corn oil has been instilled into the lumen conspicuous 
enzymatic modifications occur in the absorptive cells at the tops of the duodenal villi when the fat absorption is important.

The most frequent modification is the increase in NADH2-TR, which catalyses NADH2 dehydrogenation.

The activation of both NADH2-TR and NADPH2-TR is related to oxydative phosphorylation and ATP synthesis. The increase in NADH2-TR activity observed is in agreement with the activation of this enzyme already observed in the duodenum of rats fed with a diet enriched with vegetable fat (Wegmann et al, 1967). This modification of mitochondrial enzyme activity corresponds to the alterations in the mitochondrial ultrastructure observed in the absorptive cells of rats to which corn oil was given orally (Gonzalez-Licea, 1971).

The increase in glucose-6-phosphate dehydrogenase (G-6-PD) and NADPH2-TR indicates stimulation of the pentose phosphate pathway which provides the NADPH2.

The decrease in lactate dehydrogenase (LD) activity observed was also noted in the duodenal villi of rats fed with vegetable fat (Wegmann et al, 1967).

\section{References}

Barka, T. (1963). Fat absorption and acid phosphatase activity in intestinal epithelium of mice. J. Amer. med. Ass., 183, 761-764.

Debray, C., Cerf, M., Marche, C., and Bertin, D. (1969). Morphologie de l'absorption des graisses dans le jéjunum. Etude biopsique. Arch. Mal. Appar. dig., 58, 5-24.

Dobbins, W. O. (1968). Electron microscopy of intestinal fat absorption under normal conditions and in malabsorptive states. In Prog. Gastroent., p. 261-276.

Dobbins, W. O. (1969). Morphologic aspects of lipid absorption. Amer. J. clin. Nutr., 22, 257-265.

Gomori, G. (1941). The distribution of phosphatase in normal organs and tissues. J. cell comp. Physiol., 17, 71-83.

Gomori, G. (1942). Distribution of acid phosphatase in the tissues under normal and pathologic conditions. Arch. Path., 32, 189-199.
González-Licea, A. (1971). An ultrastructural study of intestinal mitochondrial morphology during the absorption of various nutrients and water in suckling rats. Lab. Invest., 24, 273-278.

Higgins, J. A., and Barrnett, R. J. (1971). Fine structural localization of acyltransferases: the monoglyceride and a-glycerophosphate pathways in intestinal absorptive cells. J. Cell Biol., 50, 102-120.

Housset, E., Wegmann, R., Guesde, M., and Nepveux, P. (1967). Influence du régime alimentaire sur les activités histoenzymatiques du foie et de l'intestin du rat. Ann. Histochim., 12, 379-390.

Johnston, J. M. (1968). Mechanism of fat absorption. In Handbook of Physiology, Sect. 6, The Alimentary Canal, edited by C. F. Code, Vol. III, Intestinal Absorption, 1353-1375. American Physiological Society, Washington, D.C.

Kayden, H. J., Senior, J. R., and Mattson, F. H. (1967). The monoglyceride pathway of fat absorption in man. J. clin. Invest., 46, 1695-1703.

Kern, F., and Borgström, B. (1965). Quantitative study of the pathways of triglyceride synthesis by hamster intestinal mucosa. Biochim. biophys. Acta (Amst.), 98, 520-531.

Lewis, A. A. M., and Hunter, R. L. (1966). The effect of fat ingestion on the esterase isozymes of intestine, intestinal lymph, and serum. J. Histochem. Cytochem., 14, 33-39.

Nachlas, M. M., and Seligman, A. M. (1949). The histochemical demonstration of esterase. J. nat. Cancer Inst., 9, 415-425.

Nachlas, M. M., Walker, D. G., and Seligman, A. M. (1958). The histochemical localization of triphosphopyridine nucleotide diaphorase. J. biophys. biochem. Cytol., 4, 467-474.

Padykula, H. A., and Herman, E. (1955). Factors affecting the activity of adenosine triphosphatase and the other phosphatases as measured by histochemical technique. J. Histochem. Cytochem. 3, 161-169.

Parmentier, C. M. (1962). Histologic demonstration of intestinal fat absorption in man with an improved carbowax technique. Gastroenterology, 43, 1-9.

Przelecka, A., Ejsmont, G., Sarzala, M. G., and Taracha, M. (1962). Alkaline phosphatase activity and synthesis of intestinal phospholipids. J. Histochem. Cytochem., 10, 596-600.

Scarpelli, D. G., Hess, R., and Pearse, A. G. E. (1958). The cytochemical localization of oxydative enzymes. I. Diphosphopyridine nucleotide diaphorase and triphosphopyridine nucleotide diaphorase. J. biophys. biochem. Cytol., 4, 747-752.

Seligman, A. M., Tsou, K. C., Rutenburg, S. H., and Cohen, R. B. (1954). Histochemical demonstration of $\beta$-D-glucuronidase with a synthetic substrate. J. Histochem. Cytochem., 2, 209-229.

Tuba, J., and Robinson, M. I. (1953). The response of intestinal alkaline phosphatase of fasted rats to forced feeding of fat. J. biol. Chem., 203, 947-951.

Wegmann, R., and Gerzeli, G. (1961). La glucose-6-phosphate deshydrogénase et ses corrélations avec des substrats voisins du glucose-6-phosphate. Role de l'hexokinase. Ann. Histochim., 6, 111-124.

Wegmann, R., and Tordet-Caridroit, C. (1960). Histochemical demonstration of succinic dehydrogenase by specific inhibition and activation. (Abstr.) J. Histochem. Cytochem., 8, 348-349. 